\title{
MUC6 wt Allele
}

National Cancer Institute

\section{Source}

National Cancer Institute. MUC6 wt Allele. NCI Thesaurus. Code C158560.

Human MUC6 wild-type allele is located in the vicinity of 11 p15.5 and is approximately 24 $\mathrm{kb}$ in length. This allele, which encodes mucin- 6 protein, plays a role in the formation of a protective layer of mucus in the gastrointestinal tract. 